\title{
Modelling Students' Experience Towards the Development of Alumni Involvement and Alumni Loyalty
}

\author{
U. N. Saraih ${ }^{1 *}$, Nor Irwani Abdul Rahman ${ }^{1}$, Norshahrizan Noordin ${ }^{1}$, Sayang Nurshahrizleen Ramlan ${ }^{1}$, Razli \\ Ahmad $^{2}$, Mohd Fo' ad Sakdan ${ }^{2}$ and M. Harith Amlus ${ }^{1}$ \\ 1School of Business Innovation and Technopreneurship, Universiti Malaysia Perlis (UniMAP), Malaysia \\ ${ }_{2}$ School of Human Development and Technocommunication, Universiti Malaysia Perlis (UniMAP), Malaysia.
}

\begin{abstract}
The purpose of this study is to investigate the influence of students' experience towards the development of alumni involvement and alumni loyalty in Malaysia. This study utilized the survey (questionnaire) method. Data are gathered from 347 respondents in one of the Public Higher Educational Institution (PHEI) in Malaysia. Results presented that students in this institution have low levels of alumni involvement (mean=1.23) and alumni loyalty (mean=1.76). Results also presented that in this institution, students' experience is significantly related to alumni involvement $(\beta=.42, \mathrm{p}<.01)$ and alumni loyalty $(\beta=.57, \mathrm{p}<.01)$. This study contributed some new knowledge which can be channelled to all PHEIs in Malaysia to improve the level of alumni involvement and alumni loyalty. Good experience of students can be cultivated by improving several aspects on managerial side. Some recommendations to increase the level of students' experience are discussed.
\end{abstract}

\section{Introduction}

Alumnus is one of significant party in any university's community. Thus, fostering a lifelong connection with current students, and later the alumni, is a potential source of support for institutions [1]. Based on the existing literature, undergraduate students who have a positive and satisfying experience in the university tend to develop lifelong relationships as alumni with the institution. Positive experiences include enjoying classes, developing friendships and obtaining a useful degree [2]. Meanwhile, being satisfied with the undergraduate experience could mean obtaining a job upon graduation or getting connected to worthwhile efforts that offer challenge for the graduate.

Recognizing the importance of alumni to the university in enhancing networks and connecting community for the local and international level, Ministry of Higher Education Malaysia (MoHE) has taken the initiative by making alumni as one party to realize the goals of internationalization. Therefore, to realize the goals of universities' internationalization, it is expected that alumni need to be involved and loyal to the university. Alumni studies are useful not only to assess institutional effectiveness but also to aid institutional planning and revenue generation. Alumni are important sources of information and support, and alumni studies should occupy a prominent place in the institutional research portfolio [3]. The first objective of this study is to reveal the relationship between students' experience in the university and their intention to involve when they become the alumni for the university. According to [4], an active involvement of alumni enables them to contribute their wealth to the former alma mater. Besides alumni involvement, loyal alumni also play an important role to the institution performance. Hence, understanding on how loyalty is formed is a key factor to shape loyalty while alumni are students. Therefore, the second objective of this study is to reveal the relationship between students' experience in the university and their intention to be loyal to the university after they become the alumni. As stated by [5], the benefit of alumni loyalty to institutions is immeasurable. This include volunteerism of alumni, hiring graduates, recruiting students, and making financial contributions. Moreover, in this current economic situation, alumni loyalty is something which all institutions cannot ignore [5].

Given that alumni loyalty is formed while they are students [5], and alumni who are more satisfied with their educational experience have greater level of alumni involvement [6]; thus, forming an understanding of the experiences which students have with their alma maters would provide insights into the future alumni attitudes (eg. alumni involvement, alumni loyalty). In other word, students' experience in the university is the best platform to reveal the intention of the future alumni involvement and alumni loyalty.

\footnotetext{
* Corresponding author: ummi@unimap.edu.my
} 


\section{Literature Review}

\subsection{Students' Experience}

Students' experience became a popular term among the higher educational managers but is still theoretically under-developed [7]. Alumni who enjoyed their students' experience gave positive feedback to people in their networks, acted as role models for the current students, shared their skills and experiences, and advised the program of the alma mater [8]. This author found a significant correlation between students' experience and future perceptions of the institution. Many studies have stated that the strongest giving predictor is the satisfaction a student had with his or her students' experience [9]. Graduates who are satisfied with their college experience are more likely to contribute to the college or university [10]. As highlighted by [11] studying the undergraduate experience may provide a glimpse into the source of loyalty for individuals who financially contribute to their alma mater. Also, [12] found that there was a relationship between students' involvement and satisfaction with the college experience.

Besides of college experience, satisfactory interactions with faculty and staff were also critical to students' positive academic experience [13]. A research of academic experience by [14] found that the quality of teaching experienced by students is the key determinant of student loyalty. In addition, higher education has a high involvement, experientially rich service, characterized by a relatively lengthy experience [15]. Therefore, educational experience is also salient in shaping the future alumni giving.

In local context, [16] assessed how alumni relations can help the ministry in spreading information and promote the higher learning institutions. The findings indicate that relationship between students and university create a remarkable experience to alumni throughout their studies and formed a communal relationship. Thus, in this study the researchers attempt to investigate the satisfaction of students' experience in one of the PHEI in Malaysia. Based on report as presented by the Quality Department in this PHEI, the level of satisfaction among students towards this institution is still moderate. Therefore, studying students' experiences would provide insights into the existing literature in the domain of alumni

involvement and alumni loyalty.

\subsection{Alumni Involvement}

Alumni involvement is referred to the relationship which alumni had with their undergraduate institution after graduation. It include of wearing the institution's brand, promoting the institution to future students, and giving of their time, talent or treasure. There are many ways that alumni can remain involved in their alma mater. They can attend alumni events, speak in classes, serve on university or alumni association committees, assist with admissions, offer internships, and support numerous other areas. Several researchers have studied the impact of alumni involvement has on giving and found it has a positive correlation. Existing literature also confirmed that alumni are more likely to be donors, are more likely to be repeated donors, with size of the gift strongly related to the involvement.

According to [5], alumni involvement referred to those who feel included and participated in university activities and engaged in some way with the life of the institution. Examples would be holding volunteer positions, attending alumni events or engaging in some other way with the university. In a local context, [4] stated that the active involvement of the alumni contributed their wealth to their former university. As presented by [6] alumni, who are more satisfied with their educational experience, and who are more involved in students' life during undergraduates, have greater involvement in alumni activities (high alumni involvement). This was supported by [13] who presented that alumni involvement predicted donation behavior; and alumni involvement is predicted by several factors such as MBA satisfaction, university prestige, and current salary.

\subsection{Alumni Loyalty}

Most of the previous studies tend to examine the factors of students' loyalty instead of studying the factors of alumni loyalty. For example, factors of university's image perceived by students and student satisfaction have been tested as potential predictors of students' loyalty in Portugal [17]. Similarly, other factors such as image of study program, image of the University College and student satisfaction have been examined as the predictors of students' loyalty in a Norwegian University College [18]. Therefore, several factors of students' loyalty have been investigated in the previous studies, however limited evidence is known on a comprehensive explanation of how long-term students' loyalty is generated and sustained [19].

Although [14] presented that students' loyalty only involved in long-term relationships, [19] argued that it seemed unclear on how post-graduation loyalty (alumni loyalty) can be generated unless it is backtracked to the school years in order to understand its sources and antecedents. Loyalty can mean different things to different people and can have many definitions depend on the context in which it is used [20]. As defined by [21] loyalty was unswerving in allegiance, faithful to a cause, ideal, custom, institution, or product. Students' loyalty has been as a deep relational and emotional bond the student develops for the university [14]. As claimed by [22] efforts should be taken to ensure that alumni are connected to their university to enhance their loyalty. Thus, all institutions must strategically identified what was the most important to the graduates and determined what made the greatest long term impact on their educational experience to develop the alumni loyalty [20]. Given all the literature, the specific hypotheses are developed as follows: 
$\mathrm{H}_{1}$ : There is a moderate level of alumni involvement in this institution.

$\mathrm{H}_{2}$ : There is a moderate level of alumni loyalty in this institution.

H3: There is a significant relationship between students' experience and alumni involvement in this institution.

H4: There is a significant relationship between students' experience and alumni loyalty in this institution.

\section{Methodology}

The population of this research included all of final year students from all faculties in the institution. This study utilized the quantitative method (eg. questionnaire). Questionnaires are distributed randomly for 500 respondents. The SPSS software (version 22) has been used for the statistical analysis. The instruments used for alumni involvement and alumni loyalty have been adapted from previous measurements. However, the instrument used for students' experience had been developed based on the environment of the institution. Students need to respond their satisfaction towards the four dimensions of experience consist of teaching and learning activities (3 items), dealing with several departments in the institution (6 items), co-curricular activities (2 items), and their intention as the future alumni ( 2 items). As for the alumni attitudes, 3 items of [23] and 5 items of [20] have been adapted for alumni involvement and alumni loyalty.

Based on the pilot test, the reliability values of students'

experience, alumni involvement and alumni loyalty are reported at $.87, .83$ and .62 each. In this study, the researchers used the criteria of Cronbach's alpha as established by [24]. Therefore, the reliabilities of variables used in this research are ranged from acceptable to good which mean that all variables can be used for further analysis.

\section{Results and Discussions}

A quantitative approach has been used in this study. Questionnaires has been utilized as the primary instrument to collect data from the respondents. The total returned questionnaires that could be used was 347, which was $69.4 \%$ of the total distributed questionnaires.

\subsection{Respondent's Background}

Most of the respondents in this study were female, $58.8 \%$ (204 participants); and the remaining 41.2\% (143 participants) were male. The highest percentage of responses $(20.5 \%)$ are contributed from School of Business Innovation and Technopreneurship; and the lowest percentage of responses (7.6\%) are obtained from School of Material Engineering. Other responses were from School of Electrical Systems Engineering (14.1\%), School of Microelectronics Engineering (12.1\%), School of Computer and Communication Engineering (9.5\%), School of Human Development and
TechnoCommunication (9.8\%), School of Bioprocess Engineering $(8.9 \%)$, School of Environmental Engineering (8.9\%) and School of Mechatronics Engineering $(8.6 \%)$.

\subsection{Reliability Analysis}

The Cronbach's alpha values are reported at .76 for alumni involvement, .79 for alumni loyalty and .82 for students' experience. According to [24], the Cronbach's alpha values showed that all of the variables are good in this study.

\subsection{Mean and SD Analysis}

In this study, the interpretation of mean scores has been referred to the previous authors [25]. According tho these authors, the mean scores ranged from low (1.00$2.00)$, moderately low (2.01 -3.00), moderately high (3.01 -4.00) to high (4.01 -5.00). As presented in Table 1 , the mean value for students' experience was 1.25. Therefore, low acceptance is observed for this variable. Almost similar means score are recorded for alumni involvement; 1.23 and alumni loyalty; 1.76 . Thus, H1: There is a moderate level of alumni involvement in this institution and H2: There is a moderate level of alumni loyalty in this institution are not supported in this study.

Table 1. Mean and SD Values

\begin{tabular}{|c|c|c|c|}
\hline Variables & N & Mean & SD \\
\hline Students' Experience & 347 & 1.25 & .21 \\
\hline Alumni Involvement & 347 & 1.23 & .20 \\
\hline Alumni Loyalty & 347 & 1.76 & .29 \\
\hline
\end{tabular}

As for the SD analysis, it is noted that the SD values for students' experience (.21), alumni involvement (.20) and alumni loyalty (.29) were also low. The low level of SD showed that most respondents were close to the mean for variables in this study.

\subsection{Correlation Analysis}

Pearson correlation coefficient (r) is computed to examine the correlations and directions among the study variables. This analysis had been conducted to determine the interdependency of the study variables. As presented in Table 2, strong relationship are observed between students' experience and alumni loyalty $(\mathrm{r}=.53, \mathrm{p}<.01)$; and between alumni loyalty and alumni involvement $(\mathrm{r}=.57, \mathrm{p}<.01)$. Meanwhile, moderate relationship is remarked for correlation between students' experience and alumni involvement $(\mathrm{r}=.42, \mathrm{p}<.01)$. In sum, all correlations are reported as significantly and positively between each other. 
Table 2. Correlation Analysis

\begin{tabular}{|c|c|c|c|c|}
\hline Variables & $\mathbf{N}$ & $\mathbf{1}$ & $\mathbf{2}$ & $\mathbf{3}$ \\
\hline Students' Experience & 347 & - & & \\
\hline Alumni Involvement & 347 & $\begin{array}{c}.42^{*} \\
*\end{array}$ & - & \\
\hline Alumni Loyalty & 347 & $\begin{array}{c}.53^{*} \\
*\end{array}$ & $\begin{array}{c}.57^{*} \\
*\end{array}$ & - \\
\hline
\end{tabular}

**Correlation is significant at the 0.01 level (2-tailed)

\subsection{Regression Analysis}

As presented in Table 3, students' experience only explained $18 \%$ of variance in alumni involvement $(\mathrm{R} 2=.18)$. To further clarify, only $18 \%$ is explained by students' experiences, while the rest of $82 \%$ of variance in alumni involvement is explained by the other variables. Meanwhile, the adjusted R2 value also taken into account as .17. Students' experiences is observed had strong influences on alumni involvement $(\beta=.42$, $\mathrm{p}=.00)$. Thus, H3: There is a significant relationship between students' experience and alumni involvement in this institution is supported in this study.

Next, regression result presented that students' experience explained $27 \%$ of variance in alumni loyalty $(\mathrm{R} 2=.27)$. This clarified that only $27 \%$ of variance in alumni loyalty is explained by students' experiences, while the rest of $73 \%$ of variance in alumni loyalty is explained by the other variables. Meanwhile, the adjusted R2 value also taken into account with 26 . Students' experiences had strong influences on alumni loyalty $(\beta=.57, \mathrm{p}=.00)$. Thus, $\mathrm{H} 4$ : There is a significant relationship between students' experience and alumni loyalty in this institution is supported in this study.

Table 3. Regression Analysis

\begin{tabular}{|l|c|c|c|c|}
\hline \multicolumn{1}{|c|}{ Variables } & \multicolumn{4}{c|}{ Students' Experience } \\
\hline & Beta & Sig. & $\mathrm{R}^{2}$ & $\begin{array}{c}\text { Adjusted } \\
\mathrm{R}^{2}\end{array}$ \\
\hline Alumni Involvement & $.42^{* *}$ & .00 & .18 & .17 \\
\hline Alumni Loyalty & $.57^{* *}$ & .00 & .27 & .26 \\
\hline
\end{tabular}

**Correlation is significant at the 0.01 level (2-tailed)

\section{Conclussion}

The results of this study presented that the level of alumni involvement and alumni loyalty among students in this institution were in the low indications with the mean value reported at 1.23 and 1.76 each. Therefore, H1: There is a moderate level of alumni involvement in this institution; and H2: There is a moderate level of alumni loyalty in this institution are not supported this study.

In addition, this study provides some new knowledge pertaining the influence of students' experiences on alumni involvement and alumni loyalty. As presented in Table 4, students' experience are positively associated with alumni involvement $(\beta=.42, \mathrm{p}<.01)$ and alumni loyalty $(\beta=.57, \mathrm{p}<.01)$.
Therefore, H3: There is a significant relationship between students' experience and alumni involvement in this institution, and H4: There is a significant relationship between students' experience and alumni loyalty in this institution are supported in this study.

Based on the results, it can be concluded that by increasing the level of students' experiences among the current students in this institution, the future level of alumni involvement and alumni loyalty among them can be enhanced. In the theoretical perspective, these findings had been consistent with the previous findings as reported by several authors.

For instance, [13] found that alumni involvement is predicted by factors such as MBA satisfaction and university prestige. It is presented that alumni, who are more satisfied with their educational experience have greater involvement in alumni activities [6]. Moreover, [18] presented that positive relationships between students' satisfaction and alumni loyalty in Norwegian University College. Previous findings of [11] also found that undergraduate experience are related to alumni loyalty to their alma mater.

In the practical perspective, the top management may allocate several new efforts to increase the level of students' experience such as: 1) To create a platform for further interaction between students and the academic staff even after teaching and learning session; 2) To create a platform for further interaction between students and the non-academic staffs even after office hours; 3 ) To enhance the implementation of the buddy system; and 4) To provide a more effective interaction medium in serving students pertaining several complaint related to the University's library, Bursary Department, ICT Department, Residential Colleges, Students Affair and Alumni Department, etc.

\section{References}

1. Pulley, J. The journey is the reward. Currents, 39(1), 16-21 (2013)

2. Berquam, L.M. Affinity development in undergraduate students at a large research institution, Doctoral Dissertation, Colorado State University (2013)

3. Volkwein, J.F. Assessing alumni outcomes. New Directions for Institutional Research, 125-139. doi:10.1002/ir.335 (2010)

4. Muhammad, F., Abdul Razak, A., Mohd Hussin, M.Y. \& Awang, S.A. Willingness of the alumni to contribute to their university: A study among Muslim teachers in Johor, Shariah Journal, 22(2), 259-288 (2014)

5. Vanderbout, J.L. Impact the undergraduate student experience has on the development of alumni loyalty, Doctoral Dissertation, University of MissouriColumbia (2010)

6. Hoyt, J.E. Understanding alumni giving: Theory and predictors of donor status. Paper presented at the meeting of the Association of Institutional Research (2004) 
7. Koenig-Lewis, N., Asaad, Y., Palmer, A. \& Petersone, E. The effects of passage of time on alumni recall of student experience. Higher Education Quarterly, 70(1), 59-80 (2016)

8. Hansen, L.L. Once students, forever alumni: A study analyzing drivers of alumni loyalty, Master Thesis, Carthage College (2015)

9. Stephenson, A.L. \& Bell, N. Motivation for alumni donations: A social identity perspective on the role of branding in higher education. International Journal of Nonprofit and Voluntary Sector Marketing, 19, 176-186 (2014)

10. Sun, X., Hoffman, S. \& Grady, M. A multivariate causal model of alumni giving: Implications for alumni fundraisers. International Journal of Educational Advancement, 7(4), 307-332 (2007)

11. Mercatoris, M.E. Alumni loyalty: Examining the undergraduate college experience and alumni donations, Doctoral Dissertation, University of Texas (2006)

12. McAdoo, A.D. Factors affecting the institutional perception of alumni of the University of Arkansas, Doctoral Dissertation, University of Arkansas (2010)

13. Baruch, Y. \& Sang, K.J.C. (2012). Predicting MBA graduates' donation behavior to their alma mater. Journal of Management Development, 31(8), 808825 (2012)

14. Hennig-Thurau, T., Langer, M.F. \& Hansen, U. Modeling and managing student loyalty: An approach based on the concept of relationship quality. Journal of Service Research, 3(4), 331 -344 (2001)

15. Woodall, T., Hiller, A. \& Resnick, S. Making sense of higher education: Students as consumers and the value of the university experience. Studies in Higher Education, 1 -20.doi: 10.1080/03075079.2011648373 (2012)
16. Mohd Rashid, N.A., Kee, C. P. \& Mohamed Salleh, S. Internationalization of Malaysia Higher Education through experience of Indonesian alumni with alma mater, Journal of Social Science and Humanities, 10(2), 261 -273 (2015)

17. Alves, H. \& Raposo, M. Conceptual model of student satisfaction in Higher Education, Total Quality Management, 18(5), 571 -588 (2007)

18. Helgesen, Ø. \& Nesset, E. What accounts for students' loyalty? Some field study evidence. International Journal of Educational Management, 21(2), 126-143 (2007)

19. Rojas-Mendez, J.I., Vasquez-Parraga, A.Z., Kara, A. \& Cerda-Urrutia, A. Determinants of student loyalty in higher education: A tested relationship approach in Latin America. Latin American Business Review, 10, $21-39$ (2009)

20. Breland, J.R. Development and validation of the alumni loyalty scale, Doctoral Dissertation, University of Alabama at Birmingham (2012)

21. loyalty. 2017. In Merriam-Webster.com. Retrieved June 2017, from https://www.merriamwebster.com/dictionary/loyal

22. Lertputtarak, S. \& Supitchayangkool, S. Factors influencing alumni donations, International Journal of Business and Management, 9(3), 170-178 (2014)

23. Sharkness, J. \& DeAngelo, L. Measuring student involvement: A comparison of classical test theory in the construction of scales from students surveys, Research in Higher Education, 52(5), 480-507 (2011)

24. George, D. \& Mallery, P. SPSS for Windows step by step: A simple guide and reference (4thed.). Boston: Allyn \& Bacon (2003)

25. Norasmah, H.O. \& Salmah, I. Kecenderungan terhadap pemilihan kerjaya keusahawanan mengikut persepsi peserta skim usahawan siswa. Jurnal Teknologi, 56, 47-63 (2011) 